\title{
Identifikasi Komposisi Kimia dan Uji Aktivitas Antioksidan dari Biji Kurma (Phoenix dactylifera)
}

\section{Idenfification Chemical Compounds and Antioxidant Analisys from Seed Kurma (Phoenix dactylifera)}

\author{
Yusraini Dian Inayati Siregar ${ }^{1}$, Tarso Rudiana ${ }^{1,2}$, Windi Riyadi ${ }^{1}$ \\ ${ }^{1}$ Program Studi Kimia Fakultas Sains dan Teknologi, UIN Syarif Hidayatullah Jakarta \\ Jalan Ir. H. Juanda No. 92, Ciputat Tangerang Selatan Banten15412, Indonesia \\ ${ }^{2}$ Program Studi Kimia Fakultas Sains dan Farmasi Universitas Mathla'ul Anwar Banten \\ Jalan Raya Raluan KM 23, Pandeglang Banten 42273, Indonesia \\ Email: yuskimia@uinjkt.ac.id
}

Received: March 2018; Revised: April 2018; Accepted: August 2018; Available Online: November 2018

\begin{abstract}
Abstrak
Biji kurma adalah bagian komponen buah kurma yang memiliki 6.10-11.47\% dari keseluruhan buah kurma. Di beberapa negara, biji kurma menjadi masalah utama pada industri pengolahannya karena bijinya saat ini hanya menjadi limbah. Penelitian ini dilakukan untuk menentukan pelarut yang menghasilkan rendemen terbesar menggunakan metode sokletasi dan menentukan aktivitas antioksidannya. Biji kurma disokletasi dengan variasi pelarut yaitu $n$-heksana, dietil eter, dan etanol serta variasi waktu ekstraksi selama $1.5 ; 2.0$; dan 2.5 jam. Berdasarkan hasil penelitian menunjukkan bahwa hasil ekstrak biji kurma terbesar diperoleh menggunakan etanol sebesar $4.93 \%$ selama $2.5 \mathrm{jam}$. Aktivitas antioksidan ekstrak biji kurma $\left(\mathrm{IC}_{50}\right)$ dengan menggunakan metode DPPH ekstrak etanol, ekstrak $n$-heksana dan dietil eter dengan masing-masing $\mathrm{IC}_{50}$ sebesar 2.27; 8396.56; dan 9826.88 ppm. Penghambatan ekstrak biji kurma menggunakan metode TBA berasal dari ekstrak etanol sebesar $98.22 \%$ pada konsentrasi $250 \mathrm{ppm}$. Hasil analisis menggunakan LC-MS diduga bahwa ekstrak etanol mengandung senyawa asam 13-hidroksiabsisat, 1-etiliden-4-metiliden-2-okso-7- (propan-2-il)-oktahidro1H-inden-5-il-3-metilpent-2-enoat, asam-12-hidroksi-(8,10,14)-eikosatrienoat dan 1-hidroksi-3(pentadekanoiloksi) propan-2-il-(5,8,11,14)-ikosa-5,8,11,14-tetraenoat. Hasil analisis menggunakan GC-MS terhadap ekstrak $n$-heksana diduga mengandung senyawa 2,4-di-tert-butilfenol dan asam 9-oktadekanoat. Ekstrak dietil eter diduga mengandung asam 9-oktadekanoat dan asam benzokarboksilat 1,2benzenedikarboksilat, mono-(2-etilheksil).
\end{abstract}

Kata kunci: Antioksidan, biji kurma, DPPH, Phoenix dactylifera, TBA

\begin{abstract}
Dates are a component of dates that have $6.10-11.47 \%$ of all dates. In some countries, dates are a major problem in the processing industry because the seeds currently only become waste. This research was conducted to determine the solvent that produces the largest yield using the soxhletation method and determine its antioxidant activity. Dates are disoxletasion with a variety of solvents n-hexane, diethyl ether, and ethanol. Also carried out the variation of extraction time for $1.5 ; 2$; and 2.5 hours. Based on the results of the study showed that the results of the largest date seed extract were obtained using ethanol of $4.93 \%$ for 2.5 hours. Antioxidant activity of date palm seed extract $\left(\mathrm{IC}_{50}\right)$ using DPPH ethanol extract method has $\mathrm{IC}_{50}$ of $2.27 \mathrm{ppm}$; n-hexane extract 8396.56 ppm; and diethyl ether extract $9826.88 \mathrm{ppm}$. Inhibition of date palm seed extract using the TBA method derived from ethanol extract of $98.22 \%$ at a concentration of $250 \mathrm{ppm}$. The results of the analysis using LC-MS showed that ethanol extract was thought to contain 13-hydroxyabscisic acid compound, 1-ethylidene-4-methylidene-2oxo-7-(propan-2-il)-tocahydro-1H-indent-5-il- 3-methylpent-2-enoate, 12-hydroxy-acid $(8,10,14)$-eicosatrienoic and 1-hydroxy-3- (pentadecanoiloxy) propan-2-il $(5,8,11,14)$-icosa-5, 8,11,14-tetraenoate. The results of the
\end{abstract}


analysis using GC-MS on n-hexane extract showed 2,4-di-tert-butylphenol and 9-octadecenoic acid. Diethyl ether extract contains 9-octadecenoic acid and mono (2-ethylhexyl) benzocarboxylic acid.

Keywords: Date Pits; Phoenix dactylifera, Antioxidant, DPPH, TBA.

DOI:http://10.15408/jkv.v4i2.8818

\section{PENDAHULUAN}

Kurma (Phoenix dactylifera Linn) adalah salah satu tanaman tertua yang tumbuh di daerah Timur Tengah dan Afrika Selatan yang semakin berkembang menjadi obat tradisional terhadap berbagai penyakit. Biji kurma mengandung banyak senyawa fungsi bernutrisi seperti, serat, lemak, protein, kadar air dan abu, vitamin, dan sejumlah besar fenolat (Al-Farsi et al., 2007).

Limbah biji kurma dalam berbagai proses industri terbilang cukup tinggi yaitu sekitar 6,10-11.47\% dari buah kurma adalah bijinya (Habib dan Ibrahim, 2009). Pemanfaatan limbah biji kurma semakin berkembang tidak hanya sebagai bahan makanan tambahan bagi hewan ternak. Di Arab, limbah biji kurma dimanfaatkan untuk membuat minuman kopi bebas kafein (Al Juhaimi et al, 2011; Baliga et al., 2011). Pemanfaatan limbah biji kurma dapat dilakukan dengan mengambil minyak yang terkandung di dalam biji. Biji kurma mengandung komponen protein dan lemak tertinggi dibandingkan daging buah kurma (AlFarsi dan Lee, 2011). Biji kurma memiliki kandungan jumlah minyak lebih besar (9.0 g/100 g) dibandingkan daging buah kurma (AlFarsi dan Lee, 2008). Minyak dari biji kurma dapat digunakan di bidang kosmetik, farmasi, dan makanan (Baliga et al., 2011; Boukouada, 2009).

Minyak biji kurma yang diperoleh dapat dimanfaatkan dalam berbagai bidang karena memiliki aktivitas antioksidan dengan nilai $\mathrm{IC}_{50}$ sebesar 78.03 ppm (Al Juhaimi et al., 2011). Tubuh manusia membutuhkan antioksidan untuk melindungi tubuh dari serangan radikal bebas (Sayuti dan Yenrina, 2015). Minyak biji kurma secara umum dapat diekstraksi menggunakan pelarut organik dengan menggunakan metode sokletasi. Penggunaan pelarut dan waktu optimum dalam proses ekstraksi biji kurma dapat mempengaruhi hasil ekstraksi dan aktivitas antioksidan, sehingga pada penelitian ini dilakukan ekstraksi biji kurma menggunakan metode sokletasi untuk mendapatkan persen yield tertinggi dari tiga jenis pelarut. Minyak biji kurma hasil ekstraksi ditentukan nilai aktivitas antioksidan dengan menggunakan metode DPPH free radical scavenging assay dan metode TBA, kemudian dikarakterisasi senyawa kimia yang memiliki aktivitas antioksidan ekstrak biji kurma berdasarkan hasil analisis menggunakan Liquid Chromatography-Mass Spectrometer (LC-MS) dan Gas Chromatography-Mass Spectrometer (GC-MS).

\section{METODE PENELITIAN Alat dan Bahan}

Alat yang digunakan dalam penelitian antara lain alat-alat gelas, oven (Memmert), grinder (Fritsch), vortex (Thermolyne Maxi Mix Plus), penanggas air (Heidolph MR 3001 $K)$, vacum rotary evaporator (Heidolph Laborota 4000), timbangan analitik (Ohaus), perangkat sokletasi, spektrofotometer UV-Vis (Perkin Elmer Lambda 25), LC-MS (Acquaty UPL -XEVO G2-S QTOF), GC-MS (Shimadzu QP-2010).

Bahan utama yang digunakan dalam penelitian antara lain biji kurma yang diperoleh dari buah kurma jenis Al-Saad yang dibeli dari supermarket di daerah Jakarta. Bahan kimia yang digunakan adalah $n$-heksana (p.a), etanol (p.a), dietil eter (p.a), etil asetat (p.a), kloroform (p.a), aseton terdestilasi, betakaroten (Sigma), 2,2-dipenil-1-pikrilhidrazil (Sigma), asam linoleat (Sigma), buffer fosfat (Merck), asam thiobarbiturat (Merck), asam trikhloroasetat (Merck), larutan 1,1,3,3tetraetoksipropana (Sigma), kertas saring Whatman No.41 dan akuades.

\section{Persiapan Serbuk Simplisia}

Biji Kurma ( $P$. dactilfera L.) dicuci menggunakan air bersih, lalu dikeringkan menggunakan oven pada temperatur $60{ }^{\circ} \mathrm{C}$ selama 2 jam. Selanjutnya biji kurma diserbukkan dengan grinder hingga didapatkan serbuk halus dan disaring dengan saringan yang berukuran sebesar 18 Mesh. 


\section{Proses Ekstraksi}

Serbuk biji kurma ( $P$. dactilfera $\mathrm{L}$.) sebanyak $50 \mathrm{~g}$ dibungkus dengan kertas saring, diikat dengan tali dan dimasukkan ke dalam alat sokletasi. Pelarut sebanyak $250 \mathrm{~mL}$ dimasukkan ke dalam labu alas bulat. Digunakan pelarut $n$-heksana, dietil eter, dan etanol untuk proses sokletasi. Sokletasi dilakukan pada temperatur masing-masing titik didih pelarut, dengan variasi waktu $1.5 ; 2$; dan 2.5 jam (5-10 siklus/jam). Ekstrak yang diperoleh dipekatkan menggunakan vacum rotary evaporator pada temperatur $60{ }^{\circ} \mathrm{C}$ dengan kecepatan $90 \mathrm{rpm}$. Semua proses ekstraksi dilakukan triplo (Ali et al., 2015).

\section{Penentuan Aktivitas Antioksidan Metode DPPH (Molyneux, 2004) \\ Larutan sampel dibuat deret} konsentrasi 1.5-9.0 ppm dan masing-masing ditambahkan campuran pelarut $n$-heksana dan kloroform dengan rasio 2:3. Selanjutnya dari masing-masing larutan tersebut dipipet sebanyak $0.5 \mathrm{~mL}$ dimasukkan ke dalam tabung reaksi dan ditambahkan $4 \mathrm{~mL}$ DPPH $0.002 \%$, dihomogenkan dan diinkubasi selama 30 menit dalam ruang gelap. Kemudian campuran diukur dengan menggunakan spektrofotometer UV-Vis pada panjang gelombang $515 \mathrm{~nm}$ dan dihitung nilai konsentrasi inhibisi $\left(\mathrm{IC}_{50}\right)$. Pengukuran dilakukan pengulangan sebanyak 3 kali. Kontrol positif yang digunakan adalah vitamin $C$ dengan konsentrasi $0.5 ; 1 ; 2$ dan 4 ppm.

\section{Penentuan Aktivitas Antioksidan Metode TBA (Kikuzaki and Nakatani, 1993)}

Larutan ekstrak $n$-heksana dibuat deret konsentrasi $312.5 ; 625 ; 1250 ; 2500 ; 5000$ dan $10000 \mathrm{ppm}$. Larutan ekstrak dietil eter dibuat deret konsentrasi 312.5 ; 625; 1250; 2500; 5000 dan 10000 ppm. Larutan ekstrak etanol ibuat deret konsentrasi $0.25 ; 0.5 ; 1 ; 2$ dan $4 \mathrm{ppm}$. Larutan sampel masing-masing dipipet sebanyak $1 \mathrm{~mL}$ dan ditambahkan dengan $2 \mathrm{~mL}$ buffer fosfat $0.1 \mathrm{M} \mathrm{pH} 7.0$ dan 2 $\mathrm{mL}$ asam linoleat $50 \mathrm{mM}$ dalam etanol $99.8 \%$. Kemudian campuran dimasukkan ke dalam botol gelap berulir dan diinkubasi di penangas $40{ }^{\circ} \mathrm{C}$ selama waktu inkubasi optimum. Dua hari setelah waktu inkubasi maksimum, dilakukan pengukuran TBARS melalui metode TBA dengan mengambil $1 \mathrm{~mL}$ dari setiap larutan, kemudian ditambahkan $2 \mathrm{~mL}$ larutan TCA 5\% dan $2 \mathrm{~mL}$ larutan TBA $1 \%$ dalam asam asetat 50\%. Blanko yang digunakan adalah akuades, betakaroten sebagai kontrol positif dengan perlakuan yang sama. Campuran diletakkan di atas penangas air 100 ${ }^{\circ} \mathrm{C}$ selama 10 menit. Setelah dingin larutan disentrifugasi dengan kecepatan $3000 \mathrm{rpm}$ selama 15 menit dan diukur panjang gelombangnya pada panjang gelombang 532 $\mathrm{nm}$.

\section{Analisis Senyawa menggunakan LC-MS}

Ekstrak etanol diinjeksi sebanyak $5 \mu \mathrm{L}$ pada LC-MS melalui kolom UPLC C-18 (1.8 $\mu \mathrm{m} 2.1$ x $50 \mathrm{~mm}$ ). Laju alir $0.2 \mathrm{~mL} / \mathrm{min}$ menggunakan 2 tingkat energi, yaitu energi rendah sebesar 4 volt dan energi tinggi sebesar 25 hingga 70 volt. Fasa gerak yang digunakan adalah gradien asetonitril : akuades dengan perbandingan 5:95 hingga 95:5. Hasil pengukuran dapat diinterpretasikan menggunakan aplikasi Masslynk.

\section{Analisis Senyawa menggunakan GC-MS}

Ekstrak dietil eter dan $n$-heksana diinjeksi sebanyak $20 \mu \mathrm{L}$ pada GC-MS melalui kolom C-18 ( $2 \times 150 \mathrm{~mm}$ ) dengan laju alir 0.5 $\mathrm{mL} / \mathrm{menit}$. Hasil pengukuran dapat diinterpretasikan dengan membandingkan spektrum sampel dengan spektrum senyawa yang terdapat di dalam library.

\section{HASIL DAN PEMBAHASAN Ekstraksi Metode Sokletasi}

Ekstraksi biji kurma dilakukan berdasarkan variasi pelarut. Pemilihan jenis pelarut berdasarkan sifat pelarut seperti, polaritas pelarut terhadap sampel dan tidak dapat bereaksi dengan sampel. Tujuan penggunaan pelarut $n$-heksana dan dietil eter pada penelitian ini untuk membandingkan pelarut nonpolar yang lebih baik dalam memperoleh hasil rendemen lebih tinggi. Pelarut etanol umum digunakan dalam ekstraksi senyawa polar, karena memiliki indeks polar 4.3 dan memiliki tingkat toksisitas yang rendah. Ekstraksi dengan metode sokletasi didapatkan hasil rendemen ekstraksi biji kurma yang dapat ditunjukkan pada Tabel 1.

Rendemen ekstrak etanol lebih besar dari berbagai variasi waktu dibandingkan dengan ekstrak $n$-heksana dan dietil eter. Hal ini dipengaruhi oleh kelarutan, suhu dan lama ekstraksi yang digunakan. Kelarutan berdasarkan pada prinsip like dissolves like dan 
berkaitan dengan indeks polaritas. Pelarut etanol tidak hanya melarutkan komponen senyawa yang bersifat polar, tetapi juga komponen senyawa yang bersifat nonpolar dalam jumlah sedikit. Hal ini berdasarkan struktur molekul etanol memiliki gugus karbon yang berikatan dengan gugus $(-\mathrm{OH})$ yang bersifat polar. Selain itu, etanol memiliki bentuk struktur yang lebih kecil dibandingkan dengan struktur $n$-heksana dan dietil eter, sehingga etanol dapat menembus ke dalam dinding sel dengan mudah untuk melarutkan komponen-komponen senyawa (Rusmiati, 2010). Pelarut dietil eter dapat melarutkan komponen senyawa yang bersifat nonpolar, tetapi tidak sebanyak pelarut $n$-heksana. Hal ini disebabkan $n$-heksana memiliki indeks polaritas yang sangat rendah, sehingga bersifat sangat nonpolar. Suhu dan lama ekstraksi juga dapat mempengaruhi hasil rendemen karena berkaitan dengan penggunaan titik didih pelarut dan waktu kontak sentuh antara pelarut dengan sampel. Titik didih pelarut etanol, yaitu $70-80{ }^{\circ} \mathrm{C}$ lebih tinggi dibandingkan pelarut $n$ heksana, yaitu $60-70{ }^{\circ} \mathrm{C}$ dan dietil eter sebesar $34{ }^{\circ} \mathrm{C}$, sehingga ekstrak etanol lebih banyak dibandingkan ekstrak $n$-heksana dan dietil eter. Pelarut etanol memiliki titik didih yang tinggi sehingga menyebabkan pelarut sulit menguap dan berkondensasi, sehingga waktu kontak sentuh antara sampel dengan pelarut menjadi lebih lama.

Tabel 1. Hasil rendemen ekstrak $n$-heksana, dietil eter dan etanol biji kurma $(P$. dactylifera L.)

\begin{tabular}{lccc}
\hline \multirow{2}{*}{ Ekstrak } & \multicolumn{3}{c}{ \% Rendemen } \\
\cline { 2 - 4 } & $\mathbf{1 . 5}$ jam & $\mathbf{2 ~ j a m}$ & $\mathbf{2 . 5}$ jam \\
\hline n-heksana & 2.60 & 3.43 & 3.50 \\
dietil eter & 2.12 & 2.49 & 3.37 \\
etanol & 4.18 & 4.74 & 4.93 \\
\hline
\end{tabular}

Ekstraksi senyawa nonpolar biji kurma menghasilkan rendemen berupa minyak. Ekstraksi senyawa nonpolar yang dilakukan dengan suhu tinggi akan menghasilkan rendemen lebih besar. Titik didih pelarut $n$ heksana lebih tinggi dibandingkan dietil eter, sehingga dapat mempengaruhi viskositas minyak yang terdapat pada jaringan sel tumbuhan. Suhu yang tinggi menyebabkan kerusakan dinding sel dan viskositas minyak menjadi lebih rendah, sehingga minyak dengan mudah keluar dari jaringan sel. Angaitkar and Shende (2013) menjelaskan bahwa viskositas suatu cairan akan menurun dengan adanya kenaikan suhu. Hal ini dapat merusak senyawa aktif dan menurunkan nilai rendemen. Ekstrak $n$-heksana (a), ekstrak dietil eter (b) dan ekstrak etanol (c) dapat ditunjukkan pada Gambar 1.

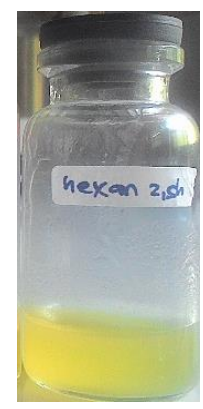

(a)

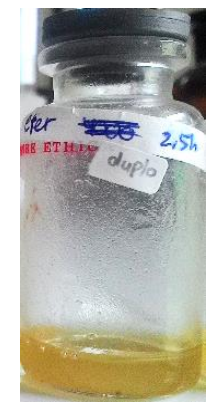

(b)

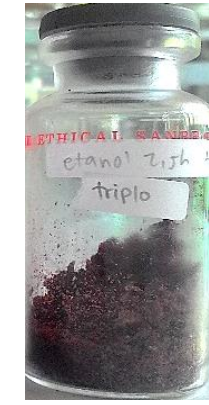

(c)
Gambar 1.Ekstrak biji kurma: (a) ekstrak nheksana (b) ekstrak dietil eter (c) ekstrak etanol

Ekstraksi biji kurma dilakukan pada waktu $1.5 ; 2$; dan 2.5 jam. Penggunaan variasi waktu ekstraksi bertujuan untuk menentukan waktu optimum ekstraksi dari hasil rendemen tertinggi yang diperoleh. Ali et al., (2015) dan Taslim et al., (2016) melaporkan bahwa waktu optimum ekstraksi biji kurma pada waktu 2 jam dari waktu ekstraksi maksimum 6 jam. Hal ini disebabkan oleh minyak berdifusi lebih cepat dari biji ke pelarut di awal proses. Perpindahan massa minyak terus meningkat hingga mencapai titik maksimum dan mencapai keseimbangan. Hasil rendemen ekstrak biji kurma tertinggi diperoleh pada waktu 2.5 jam. Hal ini dipengaruhi oleh semakin lama waktu ekstraksi, kontak antara pelarut dengan sampel semakin banyak. Lama waktu ekstraksi dapat mempengaruhi banyaknya jaringan sel yang dirusak dan dipecah akibat kontak dari pelarut dan pemanasan, sehingga pelarut mampu mengekstrak senyawa dari dalam sel lebih banyak.

\section{Aktivitas Antioksidan Metode DPPH}

Pengukuran aktivitas antioksidan dilakukan dengan penambahan larutan DPPH dengan ekstrak biji kurma, diinkubasi selama 30 menit dalam keadaan tertutup di tempat gelap. Stabilitas antioksidan dapat dipengaruhi 
oleh beberapa faktor, yaitu cahaya, oksigen dan $\mathrm{pH}$, sedangkan radikal DPPH peka terhadap cahaya, oksigen dan $\mathrm{pH}$, tetapi bersifat stabil (Giuliama et al., 2015).

Hasil pegukuran aktivitas antioksidan dapat dilihat pada Tabel 2. Rendahnya nilai $\mathrm{IC}_{50}$ ekstrak etanol menunjukkan aktivitas antioksidan lebih kuat daripada ekstrak $n$ heksana dan dietil eter, jika dibandingkan dengan kontrol positif vitamin $\mathrm{C}$ dan vitamin E. Ekstrak etanol memiliki nilai $\mathrm{IC}_{50}$ sebesar 2.27 ppm, sedangkan nilai $\mathrm{IC}_{50}$ vitamin $\mathrm{C}$ sebesar 1.99 ppm. Hal ini menunjukkan bahwa ekstrak etanol memiliki aktivitas antioksidan sama kuat dengan vitamin $\mathrm{C}$, karena nilai $\mathrm{IC}_{50}$ yang mendekati nilai $\mathrm{IC}_{50}$ kontrol positif vitamin C. Hal ini disebabkan komponen senyawa yang terkandung di dalam ekstrak etanol memiliki banyak gugus hidroksi $(-\mathrm{OH})$, sehingga mampu mereduksi radikal DPPH menjadi DPPH-H. Jika dibandingkan dengan kontrol positif vitamin $\mathrm{E}$, nilai $\mathrm{IC}_{50}$ ekstrak etanol sebesar $2.27 \mathrm{ppm}$ lebih rendah dibandingkan vitamin E sebesar $9.40 \mathrm{ppm}$. Hal ini disebabkan ekstrak etanol memiliki gugus polihidroksi lebih banyak dibandingkan vitamin $\mathrm{E}$ yang memiliki satu buah gugus hidroksi, sehingga ekstrak etanol mampu mereduksi radikal DPPH lebih banyak dibandingkan vitamin $\mathrm{E}$.

Tabel 2. Hasil uji aktivitas antioksidan ekstrak biji kurma (P. dactylifera L.)

\begin{tabular}{lc}
\hline Nama sampel & IC $_{\mathbf{5 0}}(\mathbf{p p m})$ \\
\hline Ekstrak $n$-heksana & 8396.56 \\
Ekstrak dietil eter & 9826.88 \\
Ekstrak etanol & 2.27 \\
Vitamin C & 1.99 \\
Vitamin E & 9.40 \\
\hline
\end{tabular}

Tingginya aktivitas antioksidan ekstrak etanol dipengaruhi oleh kandungan senyawa antioksidan, seperti fenolik, flavonoid, tannin, dan lain-lain. Widyowati (2015) melaporkan bahwa kadar total fenolik tertinggi didapatkan dari ekstrak etanol biji kurma (Khalas) hasil sokletasi sebesar 970.365 (mg GAE/g sampel). Senyawa fenolik bekerja sebagai antioksidan dengan cara mendonorkan atom hidrogen atau transfer elektron kepada radikal bebas DPPH.

Nilai $\mathrm{IC}_{50}$ yang diperoleh ekstrak $n$ heksana dan ekstrak dietil eter masing-masing adalah 8396.56 dan 9826.88 ppm. Ekstrak $n$ - heksana dan ekstrak dietil eter memiliki kandungan asam lemak yang tinggi dibandingkan metabolit sekundernya. Mohamed et al. (2014) melaporkan bahwa ekstrak biji kurma memiliki kandungan asam lemak yang tinggi dibandingkan komposisi metabolit sekundernya, sehingga dapat mempengaruhi aktivitas antioksidan dalam mereduksi radikal DPPH. Ekstrak $n$-heksana dan dietil eter memiliki komponen senyawa yang mengandung gugus hidroksi lebih sedikit dibandingkan dengan ekstrak etanol. Hal ini menunjukkan bahwa ekstrak $n$-heksana dan dietil eter memiliki aktivitas antioksidan yang lemah.

\section{Aktivitas Antioksidan Metode TBA}

Aktivitas penghambatan ekstrak nheksana pada konsentrasi $62.5 ; 125 ; 250 ; 500$ dan 1000 ppm masing-masing sebesar 49.08; 58.24; 54.46; 73.16 dan $71.59 \%$. Aktivitas penghambatan ekstrak dietil eter pada konsentrasi 62,5; 125; 250; 500 dan 1000 ppm masing-masing sebesar 26.26; 34.19; 62.56; 68.74 dan $64.78 \%$. Aktivitas penghambatan ekstrak etanol pada konsentrasi 62,$5 ; 125 ; 250$; 500 dan 1000 ppm masing-masing sebesar 97.67; 91.68; 98.22; 79.97 dan $80.81 \%$. Kontrol positif vitamin E memiliki aktivitas penghambatan sebesar $75.52 \%$.

kstrak $n$-heksana memiliki aktivitas penghambatan yang lebih baik dibandingkan dengan ekstrak dietil eter karena memiliki persen daya hambat yang cenderung lebih tinggi. Persen daya hambat tertinggi pada konsentrasi $500 \mathrm{ppm}$ ekstrak $n$-heksana, yaitu $79.02 \%$, sedangkan ekstrak dietil eter sebesar $68.74 \%$. Hal ini diduga komponen senyawa antioksidan yang terkandung di dalam ekstrak $n$-heksana lebih tinggi dibandingkan ekstrak dietil eter. Ekstrak $n$-heksana dan dietil eter banyak mengandung senyawa antioksidan yang bersifat nonpolar, seperti golongan terpenoid dan asam lemak (Qadir et al., 2018). Asam lemak memiliki ikatan rangkap pada rantai karbon panjang yang dapat mereduksi radikal bebas peroksida.

\section{Analisis Liquid Chromatography-Mass Spectrometry (LC-MS)}

Ekstrak etanol dianalisis menggunakan Liquid Chromatography-Mass Spectrometry (LC-MS). Berdasarkan spektrum MS ekstrak etanol diperoleh dua dugaan senyawa yang memiliki aktivitas antioksidan, yaitu Senyawa 


\section{3-(1,2)-1-hidroksi-2-}

[(metilamino)metil]sikloheksil fenol dan Senyawa 1-(4-hidroksi-3-metoksifenil)-1,4tetradekadien-3-on (Gambar 2). Senyawa 3(1,2)-1-hidroksi-2-

[(metilamino)metil]sikloheksil fenol memiliki rumus molekul $\mathrm{C}_{15} \mathrm{H}_{20} \mathrm{O}_{5}$ dengan massa molekul $[\mathrm{M}+\mathrm{H}]^{+} 281,1366 \mathrm{~m} / \mathrm{z}$. Senyawa ini terdeteksi pada waktu retensi 6.80 menit. Senyawa sikloheksil fenol merupakan senyawa fenolik tersubstitusi yang digunakan sebagai stabilisator dan antioksidan (Ecke et al., 1960).<smiles>CNC[C@@H]1CCCC[C@]1(O)c1cccc(O)c1</smiles><smiles>CCCCCCCCC/C=C/C(=O)/C=C\c1ccc(O)c(OC)c1</smiles>

Gambar 21.Struktur senyawa 3-(1,2)-1-hidroksi-2[(metilamino)metil]sikloheksil fenol dan 1-(4-hidroksi-3-metoksifenil)-1,4tetradekadien-3-on (Li et al., 2012)

Senyawa 1-(4-hidroksi-3-metoksifenil)-1,4tetradekadien-3-on atau dehidroshogaol memiliki rumus molekul $\mathrm{C}_{21} \mathrm{H}_{30} \mathrm{O}_{3}$ terdeteksi pada waktu retensi 13,24 dengan massa molekul $[\mathrm{M}+\mathrm{H}]^{+}$sebesar $331.2240 \mathrm{~m} / \mathrm{z}$. Senyawa 1-(4-hidroksi-3-metoksifenil)-1,4tetradekadien-3-on memiliki gugus hidroksi yang terletak pada cincin benzena. Li et al., (2012) melaporkan bahwa senyawa 6dehidroshogaol memiliki aktivitas penghambatan tertinggi sebesar $53.3 \%$.

\section{Hasil Analisis Gas Chromatography-Mass Spectrometry (GC-MS)}

Ekstrak $n$-heksana dan dietil eter dianalisis menggunakan Gas Chromatography-Mass Spectrometry (GCMS). Berdasarkan spektrum MS ekstrak nheksana diperoleh 2 dugaan senyawa yang memiliki aktivitas antioksidan, yaitu senyawa 2,4-di-tert-butilfenol dan senyawa asam 9oktadekenoat (Gambar 3).

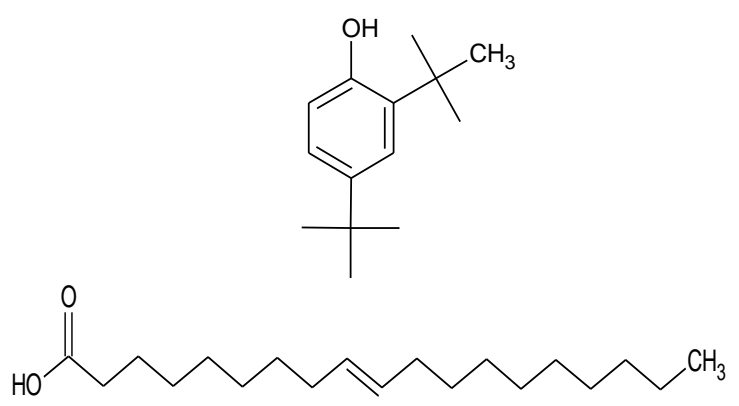

Gambar 4. Struktur senyawa 2,4-di-tert-butilfenol dan asam 9-oktadekenoat (Sukarno, 2017)

Senyawa 2,4-di-tert-butilfenol memiliki rumus molekul $\mathrm{C}_{14} \mathrm{H}_{22} \mathrm{O}$ dengan massa molekul relatif $(\mathrm{m} / \mathrm{z})$ sebesar 206. Senyawa ini terdeteksi pada waktu retensi 18.307 menit dengan luas puncak sebesar $11.27 \%$. Senyawa 2,4-di-tert-butilfenol memiliki aktivitas antioksidan diduga karena mengandung gugus hidroksi bebas yang dapat menyumbangkan proton atau atom hidrogen untuk meredam radikal bebas.

Senyawa asam 9-oktadekenoat atau asam oleat merupakan golongan asam lemak tidak jenuh dan memiliki potensi sebagai senyawa antioksidan dan antibakteri (Bharat et al., 2013). Asam oleat adalah senyawa karbon rantai panjang yang memiliki satu buah ikatan rangkap pada gugus karbon nomor 9 . Keberadaan senyawa asam oleat pada ekstrak $n$-heksana sebesar $3.25 \%$ dan pada dietil eter sebesar $11.08 \%$. Wei et al., (2016) melaporkan bahwa asam oleat dalam minyak biji Camellia tenuifolia memiliki aktivitas antioksidan yang sangat baik. Asam oleat dapat mereduksi radikal bebas dengan cara menyumbangkan satu elektron pada ikatan rangkap menjadi senyawa radikal non-reaktif.

\section{SIMPULAN}

Rendemen tertinggi pada waktu 2.5 jam diperoleh ekstrak etanol sebesar 4.93\%, sedangkan ekstrak $n$-heksana dan dietil eter sebesar 3.5022 dan 3.37\%. Ekstrak etanol memiliki aktivitas antioksidan sama kuat dengan vitamin $\mathrm{C}$ dan empat kali lebih kuat dari vitamin $\mathrm{E}$ serta persen daya hambat tertinggi diperoleh ekstrak $n$-heksana sebesar $73.16 \%$ dan dietil eter sebesar $68.74 \%$ pada konsentrasi 500 ppm, sedangkan ekstrak etanol sebesar $98.22 \%$ pada konsentrasi 250 ppm.Hasil analisis LC-MS yang diduga 
memiliki aktivitas antioksidan di dalam ekstrak etanol, yaitu 3-(1,2)-1-hidroksi-2[(metilamino)metil]sikloheksil fenol dan 1-(4hidroksi-3-metoksifenil)-1,4-tetradekadien-3on. Hasil analisis GC-MS yang diduga memiliki aktivitas antioksidan dalam ekstrak $n$-heksana, yaitu 2,4-di-tert-butilfenol dan asam 9-oktadekenoat, sedangkan dalam ekstrak dietil eter, yaitu asam 9-oktadekenoat.

\section{DAFTAR PUSTAKA}

Al-Farsi M, Alasalvar C, Al-Abid M, AlShoaily K, Al-Amry M, Al-Rawahy F. 2007. Compositional and functional characteristics of dates, syrups, and their by-products. Food Chemistry. 104.

Al-Farsi M, Lee CY. 2008. Optimization of phenolics and dietary fibre extraction from date seeds. Food Chemistry. 108: 977-985.

Al-Farsi M, Lee CY. 2011. Usage of Date (Phoenix dactylifera L.) Seeds in Human Health and Animal Feed. Elsevier Inc.

Al Juhaimi F, Ghafoor K, Ozcan MM. 2011. Physical and chemical properties, antioxidant activity, total phenol and mineral profile of seeds of seven different date fruit (Phoenix dactylifera L.) varieties. International Journal of Food Sciences and Nutrition. 63(1): 84-89.

Ali M, Al-Hattab T, Al-Hydary I. 2015. Extraction of Date Palm Seed Ooil (Phoenix dactylifera) by Soxhlet Apparatus. International Journal of Advances in Engineering \& Technology. 8(3): 261-271.

Angaitkar JN, Shende AT. 2013. Temperature dependent dynamic (absolute) scosity of oil. International Journal of Engineering and Innovative Technology. 3 (4): 449 - 454.

Baliga M, Baliga B, Kandathil S, Bath $\mathrm{H}$, Vayalil P. 2011. A review of the chemistry and pharmacology of the date fruits (Phoenix dactylifera L.).
Food Research International. 44: 1812-1822.

Bharat N, Irshad Md, Rizvi Md, Fatma T. 2013. Antimicrobial and cytotoxic activities cyanobacteria. International Journal of Innovative Research in Science, Engineering and Technology. 2(9): 4328-4343.

Boukouada M, Yousfi M. 2009. Phytochemical study of date seeds lipids of three fruits (Phoenix dactylifera L.) produced in Ouargla Region. Annales de la Faculté des Sciences et Sciences de l'Ingénieur. 1(3): 66-74.

Giuliana FE, Ardana M, Rusli R. 2015. Pengaruh $\mathrm{pH}$ terhadap aktivitas antioksidan ekstrak daun miana (Coleus Atropurpureus L. Benth). Seminar Nasional Kefarmasian Ke-1. Samarinda: Universitas Mulawarman.

Habib H, Ibrahim W. 2009. Nutritional quality evaluation of eighteen date pit varieties. International Journal of Food Sciences and Nutrition. 60: 99-111.

Kikuzaki H, Nakatani. 1993. Antioxidant effect of some ginger constituents. Journal of Food Science. 58(6): 1407-1410.

Li F, Nitteranon V, Tang X, Liang J, Zhang G, Park KL, Hu Q. 2012. In vitro antioxidant and anti-inflammatory activities of 1-dehydro-[6]gingerdione, 6-shogaol, 6dehydroshogaol and hexahydrocurcumin. Food Chemistry. 135: 332-337.

Mohamed R, Fageer A, Eltayeb M, Ahmed I. 2014. Chemical composition, antioxidant capacity, and mineral extractability of sudanese date palm (Phoenix dactylifera L.) fruits. Food Science and Nutrition. 2(5): 478-489.

Molyneux P. 2004. The use of the stable free radical diphenylpicrylhydrazyl (DPPH) for estimating antioxidant activity. Journal Science of Technology. 26(2): 211-219. 
Qadir A, Singh S, Akhtar J, Ali A, Arif M. 2018. Chemical composition of Saudi Arabian sukkari variety of date seed oil and extracts obtained by slow pyrolisis. Indian Journal of Pharmaceutical Science. 80(5): 940946.

Rusmiati. 2010. Pengaruh metode ekstraksi terhadap aktivitas antimikroba ekstrak metanol daun mimba (Azadirachta indica Juss). Makassar (ID): Universitas Alauddin.

Sayuti K, Yenrina R. 2015. Antioksidan alami dan sintetik. Padang (ID): Andalas University Press.

Sukarno. 2017. Uji aktivitas antibakteri ekstrak etanol, etil asetat dan $n$-heksana daun laruna (Chromolaena odorata L) terhadap bakteri staphylococcusaureus dan escherichia coli. [Skripsi]. Makassar (ID): Universitas Islam Negeri Alauddin.

Taslim, Agung MR, Purwanto S. 2016. Ekstraksi minyak dari biji kurma (Phoenix dactylifera L.) dengan metode soxhlet extraction dengan menggunakan etil asetat. Jurnal Teknik Kimia, 5 (2): 50 - 55.

Widyowati C.H. 2015. Identifikasi Senyawa Aktif Antioksidan Ekstrak Biji Kurma (Phoenix dactylifera). Skripsi. UIN Syarif Hidayatullah Jakarta.

Wei C, Yen P, Liao V. 2016. Antioxidative activities of both oleic acid and camellia tenuifolia seed oil are regulated by transcription factor DAF16/FOXO in caenorhabditis elegans. Research Article, 1-15. 